\title{
Region-wise development of prototypes of integrated arable farming and outdoor horticulture
}

\author{
F.G. WIJNANDS ${ }^{1} \&$ P. VEREIJKEN ${ }^{2}$ \\ ' Research Station for Arable Farming and Field Production of Vegetables, P.O. Box 430, NL \\ 8200 AK Lelystad, Netherlands \\ ${ }^{2}$ DLO-Centre for Agrobiological Research, P.O. Box 14, NL 6700 AA Wageningen, Nether- \\ lands
}

Received 23 October 1991; accepted 10 March 1992

\begin{abstract}
In the Netherlands integrated arable farming systems (IFS) are being developed at three regional experimental farms, with region-specific crop rotations and cropping systems. Most pesticide and fertilizer inputs appear to be replacable by non-chemical methods and organic manure, with economic results similar to conventional systems. The targeted reductions in pesticide use in the Netherlands' Multi-Year Crop Protection Plan for the year 2000 can already clearly be met. Further improvements of the prototype systems are considered. Recently started farming systems research for outdoor horticulture is briefly discussed.
\end{abstract}

Keywords: arable farming, integrated farming systems, IPM, environment, pesticides, crop rotation, mineral balance, fertilizers, organic manure.

\section{Introduction}

In the Netherlands, prototypes of integrated arable farming systems (IFS) are developed region-wise at three experimental farms. They are located at Nagele (since 1979) in the Central Clay area, at Borgerswold (since 1989) in the Northeastern Sand area and at Vredepeel (since 1989) in the Southeastern Sand area, representing the major soil types in arable farming.

The IFS strategy is described by Vereijken (1992) and is shared by an international working group of IFS in the International Organization of Biological and Integrated Control (Vereijken \& Royle, 1989). For the situation in the Netherlands, this general IFS strategy has been elaborated as consistent substrategies of crop protection (Vereijken, 1989a), fertilization (Vereijken, 1990) and cropping systems of winter wheat (Vereijken, 1989b), potato (Vereijken \& Van Loon, 1991) and sugar-beet (Wijnands \& Vereijken, 1989). These substrategies were recently published in a handbook of IFS for practice, extension and education (Vereijken \& Wijnands, 1990).

The IFS strategy in the Netherlands aims at reduction of high inputs of pesticides and nutrients, which are seriously affecting the quality of the biotic and abiotic 


\section{F.G. WIJNANDS AND P. VEREIJKEN}

environment. The government in the Netherlands recently accepted two policy plans to restructure and sanitize the national agriculture (Anonymous, 1990; Anonymous, 1991). The following points are most relevant for arable farming and outdoor horticulture:

- concerning pesticides, the inputs of active ingredients must be strongly reduced (50\% in 2000 compared to 1985-1988) and the spectrum of registered pesticides will be drastically sanitized (no mobile and persistent pesticides);

- concerning nutrients, the volatilization of ammonia must be strongly reduced (70\% in 2000 compared to 1985) as well as $\mathrm{N}$ and $\mathrm{P}$ emissions into the North Sea (70\% in 2000 compared to 1985). Besides, quality criteria for $\mathrm{N}$ and $\mathrm{P}$ in surface water $(2.2 \mathrm{mg} \mathrm{N} / 1$ and $0.15 \mathrm{mg} \mathrm{P} / \mathrm{l})$ and groundwater $\left(11.2 \mathrm{mg} \mathrm{N}-\mathrm{NO}_{3}^{-} / \mathrm{l}\right)$ have been set. The use of organic manure is restricted in dosage ( $\mathrm{P}$ norm), timing and application techniques. Measures including criteria of soil mineral $\mathrm{N}$ in autumn are under discussion in order to restrict $\mathrm{NO}_{3}^{-}$leaching to the groundwater.

Consequently, agriculture in the Netherlands must adopt the quality of the environment as a major objective and integrate it with the conventional objectives of income and employment. The government considers such integrated farming systems as the best way to achieve a competitive, sustainable and safe agriculture. In 1994, at least $30 \%$, and by $2000100 \%$, of the farmers should practise integrated farming, according to the policy plans (Anonymous, 1990). Therefore a project has been set up to introduce integrated farming into practice on an experimental basis, as described by Wijnands (1992). In the present article, the regional development of IFS prototypes on experimental farms is described as a preceding step.

\section{Regional development of IFS prototypes}

\section{Nagele, Central Clay area}

The most important arable production areas in the Netherlands are the Southwestern, Central and Northern Clay areas. Most of these soils are well-drained and very fertile. The small farm size (25-50 ha) urges farmers to grow financially high-yielding crops in short rotations with high inputs. Potato is the most profitable crop, followed by sugar-beet and vegetables such as onion and cabbage. Cereals are financially less attractive but are needed as break crops. Most rotations consist of only three or four years. Consequently, beet and potato cyst nematodes cause serious problems, forcing farmers to regular soil fumigation as a curative or preventive measure. In the Central Clay area ware potato and in the Northern Clay area seed potato are the most important crops. In the Soutwestern area rotations are traditionally more diversified by crops such as flax and poppies.

Besides the general IFS aims, an IFS prototype for the clay soils aims at nonchemical control of potato cyst nematodes. A potato cropping frequency of 1:4 is considered a good balance between sound rotations with lower profits (1:5 or 1:6) and financially high-yielding short rotations under pressure of pest and diseases (1:3) and therefore requiring high pesticide inputs.

The IFS prototype for clay soils has been developed since 1979 at the national 
experimental farm for the development and comparison of alternative farming systems, set up under the name 'Development of Farming Systems' (DFS) at Nagele (Northeast Polder). The size of the farm is 72 ha and the soil is heavy sandy marine clay (24\% lutum). Three farming systems have been studied until 1991: integrated, conventional, and organic (biodynamic) (Table 1). More details on this project can be found in Zadoks (1989), Vereijken (1989c), Wijnands (1990) and Hofmeester \& Wijnands (1990). The IFS prototype does not differ from conventional systems in cropping frequency of the major crops or cropping plan (Table 1) and is characterized by:

- non-chemical strategy to control nematodes, through consistent volunteer control and the use of resistant cultivars based on intensive monitoring of the pathotype and population density of potato cyst nematode infestations (Schomaker \& Been, 1990);

- reduced fungicide input through the use of resistant and tolerant cultivars, moderate fertilization levels, etc. (Integrated crop protection; Vereijken, 1989a). For instance potato cultivars are grown, which are less susceptible to potato blight (Phytophthora infestans). However, on the Dutch cultivar list, with approximately 100 recommended cultivars, it is hard to find profitable alternatives for the most common cultivar Bintje, which is highly susceptible to potato blight and nematodes and therefore depends strongly on high pesticide inputs (Vereijken \& Van

Table 1. Farming systems and crop rotations on the three experimental farms in the Netherlands (Nagele, Borgerswold and Vredepeel).

\begin{tabular}{|c|c|c|c|}
\hline Nagele & \multicolumn{2}{|c|}{$\begin{array}{l}\text { Conventional (reference) } / \text { Integrated } \\
\text { 1. } 1 / 2 \text { ware-, } 1 / 2 \text { seed potato } \\
\text { 2. } 1 / 2 \text { dry pea, } 1 / 4 \text { carrot, } 1 / 4 \text { onion } \\
\text { 3. sugar-beet } \\
\text { 4. winter wheat }\end{array}$} & $\begin{array}{l}\text { Biodynamic } \\
\text { 1. ware potato } \\
\text { 2. winter wheat } \\
\text { 3. winter carrot } \\
\text { 4./5./6. 3-year grass/clover } \\
\text { 7. onion } \\
\text { 8. winter wheat/seed } \\
\text { potato } \\
9 . / 10 . / 11 . \text { 3-year grass/ } \\
\text { clover }\end{array}$ \\
\hline Borgerswold & $\begin{array}{l}\text { Conventional (reference) } \\
\text { 1. starch potato } \\
\text { 2. sugar-beet } \\
\text { 3. starch potato } \\
\text { 4. winter wheat }\end{array}$ & $\begin{array}{l}\text { Conventional/Integrated } \\
\text { 1. starch potato } \\
\text { 2. spring wheat } \\
\text { 3. dry pea } \\
\text { 4. grass seed }\end{array}$ & $\begin{array}{l}\text { (less root crops) } \\
\text { 5. starch potato } \\
\text { 6. field bean } \\
\text { 7. sugar-beet } \\
\text { 8. winter wheat }\end{array}$ \\
\hline Vredepeel & $\begin{array}{l}\text { Integrated (more root crops) } \\
\text { 1. ware potato } \\
\text { 2. sugar-beet } \\
\text { 3. winter wheat } \\
\text { 4. scorzonera } \\
\text { 5. ware potato } \\
\text { 6. sugar-beet } \\
\text { 7. carrot } \\
\text { 8. pea/dwarf bean }\end{array}$ & $\begin{array}{l}\text { Conventional/Integrated } \\
\text { (reference) } \\
\text { 1. ware potato } \\
\text { 2. sugar-beet } \\
\text { 3. winter wheat } \\
\text { 4. scorzonera } \\
\text { 5. ware potato } \\
\text { 6. sugar-beet } \\
\text { 7. maize } \\
\text { 8. pea/dwarf bean }\end{array}$ & $\begin{array}{l}\text { Integrated (less root crops) } \\
\text { 1. ware potato } \\
\text { 2. sugar-beet } \\
\text { 3. winter wheat } \\
\text { 4. scorzonera } \\
\text { 5. ware potato } \\
\text { 6. maize } \\
\text { 7. pea } \\
\text { 8. grass seed }\end{array}$ \\
\hline
\end{tabular}


Loon, 1991). So there is an urgent need for new cultivars combining a broad resistance with a good quality for processing and consumption;

- mechanical weed control mainly based on hoeing techniques with additional band spraying of herbicides, if necessary;

- reduced $\mathrm{N}$ input and PK input/output balances on the farm level, based on environmentally safe and agronomically efficient use of organic manure according to a strategy of integrated nutrient management (INM; Vereijken, 1990).

\section{Borgerswold, Northeastern Sand area}

Farms in the Northeastern Sand area are generally small (20-40 ha) with sandy soils or reclaimed peat soils where organic matter contents vary between $3 \%$ and $20 \%$ and weed pressure is extremely high. The area strongly depends on the growing and processing of starch potato with an average cropping plan of $50 \%$ starch potato, $25 \%$ sugar-beet and $25 \%$ cereals and other crops. The gross margin of sugar-beet is the highest, followed by starch potato. All other arable crops are far less profitable. Notwithstanding the intensive use of nematicides and the use of potato cyst nematode resistant cultivars, potato cyst nematodes have heavily infested the total area (Globodera rostochiensis: $\mathrm{RO}_{1}, \mathrm{RO}_{2}, \mathrm{RO}_{3}$ and $\mathrm{RO}_{5}$; Gobodera pallida; $\mathrm{PA}_{2}$ and $\mathrm{PA}_{3}$ ). Root-knot nematodes (Melö̈ogyne hapla) are of increasing importance, since cereals, as the only non-host crop, are more and more substituted by pulses and vegetables. The high proportion of root crops makes soil fertility and soil stability decrease, because of insufficient input of organic matter and intensive soil cultivation. As a result, there are serious problems with wind erosion, especially in dry periods on fallow land. The prices of starch potatoes are under pressure since they are indirectly coupled to the EEC cereal prices. Cropping costs are high, especially for soil fumigation. So the area has gloomy perspectives and as a consequence farmers tend to set-aside. Moreover, the use of nematicides and fungicides will be restricted by law in the immediate future.

In this region, the IFS approach aims at non-chemical control of nematodes and restoration of soil fertility. It requires a more diversified crop rotation and less frequent cropping of potato (from $1: 2$ to $1: 4$ ) by increasing the proportion of monocotyledonous crops in the cropping plan (Table 1). The development of an IFS prototype for this region started in 1986 at the experimental farm Borgerswold. On this 34 ha farm, three systems are laid out: a conventional (reference) system, a diversified integrated system and a similar, but conventionally managed, system to enable differentiation between the effects of a more diversified crop rotation and integrated management (Table 1 ).

The IFS prototype for the sand and peat district is characterized by:

- sound and diversified crop rotation aimed at restoration of soil fertility in physical, chemical and biological (including soil-borne pest and pathogens) terms;

- non-chemical control of potato cyst nematodes based on a maximum cropping frequency of $1: 4$, the choice of cultivars with maximum resistance and tolerance and detailed monitoring of population density and pathotype. Additionally it is aimed at an early harvest under good soil and weather conditions, and a consistent 
volunteer control through the use of appropriate implements at harvest, noninversion tillage before winter (freezing of tubers) and, if necessary, mechanical and chemical control in the following crop. This strategy is completed by minimal turning tillage in subsequent crops to keep nematodes and fresh organic matter in the upper $10 \mathrm{~cm}$ soil layer where antagonistic activity is highest and cysts are most exposed to fluctuations of moisture and temperature. Soil life should be activated by maximum use of green and organic manure and by minimum use of chemicals. As a result, the mortality rate of the nematodes is expected to increase, which is confirmed by the preliminary results;

- mechanical weed control, in so far it does not endanger soil stability. In a rotation with a good balance between mowed and lifted crops and with minimum turning tillage, these risks are limited. On these sandy soils, harrowing is the basis for weed control in most crops, completed by hoeing and the use of herbicides in band sprays, when necessary;

- reduced fungicide input by the use of resistant and tolerant cultivars, moderate fertilization levels, etc. (Integrated crop protection: Vereijken, 1989a). A reduction of fungicide input for the potato in addition to that caused by the decrease in potato cropping frequency is hard to realize, in spite of the considerable degree of resistance of the current cultivars. High disease pressure in the region provoked by high cropping intensity of potato and the poor volunteer control is the major constraint. The use of reduced rates of fungicides with equal intervals between sprays as in the conventional system might further reduce fungicide inputs (Fry, 1978).

- reduced $\mathrm{N}$ input and PK input/output balances on the farm level, based on environmentally safe and agronomically efficient use of organic manure, as at Nagele.

\section{Vredepeel, Southeastern Sand area}

The Southeastern Sand area is characterized by a high degree of mixed plant and animal production. Most of the predominantly arable farms in this area are very small (10-30 ha) and grow financially high-yielding crops in short rotations. Many farmers have developed animal 'factory farming' units, based on high inputs of feed stuffs and maize monoculture for silage and disposal of the animal manure. The volume of indoor animal production, particularly by pigs, has increased exponentially over the last 20 years, resulting in a huge surplus of organic manure. As a result nutrient balances on the farms and in the region as a whole are seriously disrupted, which is the major cause of the disrupted national nutrient balance (Aarts et al., 1992). Dumping of manure is causing serious $\mathrm{NH}_{3}$ ager volatilization and leaching of $\mathrm{NO}_{3}{ }_{3}, \mathrm{~K}$, and even $\mathrm{P}$, when the soil gets saturated. Arable farms, whether or not with a 'factory farming' unit, mostly combine potato and sugar-beet with vegetables for the canning industry. The proportion of graminea in the cropping plan is minimal because of their low profit. The lack of stable and sound crop rotations, combined with the high proportion of root crops in the cropping plan, causes increasing problems with soil-borne pests and diseases like root-knot nematodes and Rhizoctonia 


\section{F.G. WIJNANDS AND P. VEREIJKEN}

solani. This often affects quality of root vegetables, such as carrot and scorzonera, eventually leading to price decline or even crop failure. Since winter cereals are being substituted by spring-sown crops, wind erosion and weed pressure are increasing. As a result, it is doubtful whether the farming activities are sustainable in both agronomical and economical sense.

IFS aims at a drastic sanitation of the disrupted nutrient balances, restoration of the soil stability and non-chemical control of soil-borne pests and diseases. The latter should not endanger the quality of the vegetables, so a sound and diversified crop rotation is needed. The development of prototypes of IFS was started in 1989 at the experimental farm Vredepeel (near Venray). Considering the large variation in type and scale of activities various prototypes are being studied. For the smaller holdings the question is how intensive rotations (root-crop dominated) can remain if inputs are to be reduced while maintaining quantity and quality of the output. For the larger holdings the question is to what extent rotations can be extensified while maintaining sufficient economic profit. As a result, three integrated systems are studied with various ratios between mono- and dicotyledonous crops, together with a conventional reference of the intermediate system (Table 1). Features of this regional IFS approach are:

- consistent, root-crop dominated rotations aiming at restoration of soil fertility and non-chemical prevention/control of soil-borne pests and pathogens;

- reduction of fungicide input by the use of resistant and tolerant cultivars, moderate fertilization levels, etc. The frequent irrigations, needed in dry summers, seriously hamper a reduction in fungicide-input for the potato crop. As in Borgerswold, reduced rates of fungicides used at regular intervals may help to overcome this problem;

- mechanical weed control based on harrowing and hoeing, completed with band spraying of herbicides;

- drastic sanitation of the nutrient balance by control of inputs of $\mathrm{P}$ and $\mathrm{K}$, which implies a strongly reduced use of organic manure in comparison to the conventional system. Reduction of $\mathrm{N}$ input according to the integrated nutrient management strategy.

\section{Preliminary results}

The two main criteria to evaluate the perspectives of IFS are the economic feasability and the environmental impact. For the latter, the input levels of fertilizers and pesticides are important indicators. The economic feasibility is indicated by gross margins, net farm profit and labour returns.

\section{Pesticide inputs and costs}

The total use of pesticides per year, expressed in terms of kilograms active ingredients per hectare (Table 2), is in the IFS prototypes reduced by $50-65 \%$, excluding nematicides, and even by $85-95 \%$ when nematicides are included, compared to the conventional reference systems. 
Table 2. Annual input $\left(\mathrm{kg} \mathrm{ha}^{-1}\right)$ of active ingredients of pesticides per system at the three experimental farms $(I=$ integrated, $C=$ conventional, $R=$ reference, $M R=$ more root crops, $L R=$ less root crops; see Table 1).

\begin{tabular}{|c|c|c|c|c|c|c|c|c|c|}
\hline & \multicolumn{2}{|c|}{ Nagele '86-'90 } & \multicolumn{3}{|c|}{ Borgerswold '86-' 90} & \multicolumn{4}{|c|}{ Vredepeel '89-'90 } \\
\hline & $\overline{\mathrm{C}_{\mathrm{R}}}$ & I & $\overline{\mathrm{C}_{\mathrm{R}}}$ & $\mathrm{C}_{\mathrm{LR}}$ & $I_{L R}$ & $\overline{\mathrm{I}_{\mathrm{MR}}}$ & $\mathrm{C}_{\mathrm{R}}$ & $I_{R}$ & $\mathrm{I}_{\mathrm{LR}}$ \\
\hline herbicides & 4.0 & 1.4 & 2.8 & 2.6 & 1.0 & 1.3 & 3.0 & 1.0 & 0.8 \\
\hline fungicides & 5.6 & 2.1 & 6.8 & 3.8 & 3.5 & 3.6 & 6.8 & 3.4 & 3.5 \\
\hline insecticides & 0.5 & 0.2 & 0.1 & 0.2 & 0.0 & 0.2 & 0.2 & 0.1 & 0.1 \\
\hline growth regulator & 0.3 & 0.1 & - & - & - & - & 0.0 & - & - \\
\hline subtotal & 10.4 & 3.8 & 9.7 & 6.6 & 4.5 & 5.1 & 10.0 & 4.5 & 4.4 \\
\hline nematicides & 29.7 & - & 71.4 & 38.0 & - & - & 22.3 & - & - \\
\hline total & 40.1 & 3.8 & 81.1 & 44.6 & 4.5 & 5.1 & 32.3 & 4.5 & 4.4 \\
\hline
\end{tabular}

Despite the differences in location and rotation, the herbicide input in the integrated systems hardly differs $\left(0.8-1.4 \mathrm{~kg}\right.$ a.i. ha $\left.{ }^{-1}\right)$. This means a reduction of 60 to 75\% compared with the conventional reference systems achieved by mechanical control and band spraying techniques. In all of the approximately 15 crops, herbicide use is substantially reduced while mobile, toxic and persistent chemicals are avoided. At the clay location Nagele, herbicide use can mostly be completely avoided in potato and winter wheat. At Borgerswold, the input of herbicides is comparable in both conventional managed systems. In the integrated system, it is used $65 \%$ less. At Vredepeel the herbicide input is 57,67 and $73 \%$ less in the three integrated systems, respectively, the more root-crop dominated system, the reference system and the less root-crop dominated system. At the sand locations, Borgerswold and Vredepeel, herbicides are mostly fully substituted in potato, maize, field bean, winter wheat, spring wheat and certain species of grass for seed production. Consequently, allocated costs of weed control are NLG 150-200 less per hectare at Vredepeel and Nagele (contractors costs included, machine/fuel and own labour excluded).

Fungicide inputs are reduced by 50-65\% depending on the location. At Nagele, the fungicide use in potato is reduced by more than $60 \%$ through the use of resistant cultivars and moderate nitrogen fertilization. The fungicide use in onion is also reduced by more than $60 \%$ through supervised control based on monitoring the time of initial infestation by Botrytis squamosa and weather conditions. At Borgerswold, the reduction of fungicide use is based on a $50 \%$ reduction in potato cropping frequency (Table 1). A further reduction is hampered by the very high pressure of potato blight in the region (Table 2). At Vredepeel, the major part of fungicide reduction is achieved in scorzonera by using systemic fungicides in a reduced frequency and the use of a cultivar more resistant to Erysiphe cichoracearum. The fungicide input in the three integrated systems is hardly different since the most fungicide-demanding crops, such as potato and scorzonera, are present in all three. Despite the use of more resistant potato cultivars, a reduction in fungicide input could not be achieved, because of the frequent irrigation of this crop during the last two dry summers. 
Insecticides are minimally used on all locations due to low insect pressure and the use of control thresholds, reduced-dose techniques and band spraying. In all IFS systems, the conventional use of huge amounts of soil fumigants against potato cyst nematodes has been fully substituted by a combination of non-chemical measures, particularly resistant varieties. In the conventional system at Nagele, nematicides are preventively used to protect the common potato cultivar Bintje, which is highly susceptible to potato cyst nematodes. In the conventional system at Borgerswold, soil is fumigated every second year after potato. At Vredepeel, soil is fumigated once in eight years to control all types of nematodes, but in particular to reduce the weed problem in scorzonera.

The total reduction in direct pesticide costs differs among locations (Table 4). At Nagele the reduction is NLG $480 \mathrm{ha}^{-1}$. At Borgerswold, diversification of the cropping plan alone reduces costs by NLG $260 \mathrm{ha}^{-1}\left(\mathrm{C}_{\mathrm{LR}}\right)$. Additional integrated management brings a further cost reduction of approximately NLG $300 \mathrm{ha}^{-1}\left(\mathrm{I}_{\mathrm{LR}}\right)$. At Vredepeel, the cost reduction ranges from NLG $150 \mathrm{ha}^{-1}$ for the most root-crop dominated system to NLG $240 \mathrm{ha}^{-1}$ for the reference system and the less root-crop dominated system.

\section{Nutrient inputs and costs}

The input levels of $\mathrm{P}$ and $\mathrm{K}$ in the integrated systems are considerably reduced according to the nutrient strategy of IFS (Vereijken, 1990), equalling more or less the average output from the farm (Table 3). On all three locations, $100 \%$ of the $\mathrm{P}$ demand and $60-100 \%$ of the $\mathrm{K}$ demand in the integrated systems is covered by organic manure. The applied amounts of organic manure are also covering around $60-70 \%$ of the total $\mathrm{N}$ input.

At Nagele, the inorganic $\mathrm{N}$ input is reduced by $75 \mathrm{~kg} \mathrm{ha}^{-1}$ compared with the conventional system. At Borgerswold, diversification of the crop rotation enables a reduction of $45 \mathrm{~kg} \mathrm{~N} \mathrm{ha}^{-1}$, and even $110 \mathrm{~kg} \mathrm{~N} \mathrm{ha}^{-1}$ in the case of integrated management. For Vredepeel, the inorganic $\mathrm{N}$ use is comparably low in all systems, since organic manure is traditionally the basis for the agriculture in the region. The high $\mathrm{N}$, $\mathrm{P}$ and $\mathrm{K}$ input in the conventional system of Vredepeel reflects this. The total $\mathrm{N}$ input is 65,70 and even about $150 \mathrm{~kg} \mathrm{ha}^{-1}$ lower for the integrated systems at Nagele, Borgerswold and Vredepeel, respectively, compared to the conventional reference systems. For Borgerswold there is no difference in total $\mathrm{N}$ input between the conventional $\left(C_{L R}\right)$ or integrated $\left(I_{I R}\right)$ diversified systems. From an integrated point of view the high inputs in all conventional systems are considered as agronomically unnecessary and environmentally undesirable (accumulation of nutrients, increasing risk of leaching).

Detailed nutrient balance sheets of the systems at Nagele and $\mathrm{NO}_{3}{ }^{-}$concentration assessments of the drainwater (Vereijken, 1989c) show that the lower surplus of $\mathrm{N}$ on the balance of the integrated system $\left(85 \mathrm{~kg} \mathrm{ha}^{-1}\right.$ versus $130 \mathrm{~kg} \mathrm{ha}^{-1}$ in the conventional system over 1986-1988) leads to less $\mathrm{NO}_{3}^{-}$leaching $\left(8 \mathrm{mg} \mathrm{N}-\mathrm{NO}_{3}^{-} \mathrm{l}^{-1}\right.$

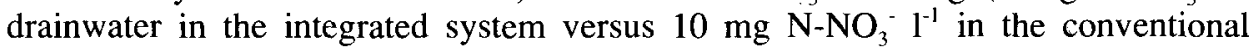
system). 
Table 3: Annual input $\left(\mathrm{kg} \mathrm{ha}^{-1}\right)$ of $\mathrm{N}, \mathrm{P}$ and $\mathrm{K}$ per system at the three experimental farms (legends: see Table 2).

\begin{tabular}{|c|c|c|c|c|c|c|c|c|c|c|}
\hline & & \multicolumn{2}{|c|}{ Nagele '86-'90 } & \multicolumn{3}{|c|}{ Borgerswold '86-' 90} & \multicolumn{4}{|c|}{ Vredepeel '89-'90 } \\
\hline & & $\mathrm{C}_{\mathrm{R}}$ & I & $\mathrm{C}_{\mathrm{R}}$ & $\mathrm{C}_{\mathrm{LR}}$ & $\mathrm{I}_{\mathrm{LR}}$ & $\mathrm{I}_{\mathrm{MR}}$ & $\mathrm{C}_{\mathrm{R}}$ & $I_{R}$ & $\mathrm{I}_{\mathrm{LR}}$ \\
\hline \multirow[t]{2}{*}{$\mathrm{N}$} & $\begin{array}{l}\text { inorganic } \\
\text { organic }\end{array}$ & $\begin{array}{r}125 \\
90\end{array}$ & $\begin{array}{r}50 \\
100\end{array}$ & $\begin{array}{r}160 \\
90\end{array}$ & $\begin{array}{r}115 \\
65\end{array}$ & $\begin{array}{r}50 \\
130\end{array}$ & $\begin{array}{r}45 \\
130\end{array}$ & $\begin{array}{r}65 \\
270\end{array}$ & $\begin{array}{r}50 \\
145\end{array}$ & $\begin{array}{r}55 \\
130\end{array}$ \\
\hline & total & 215 & 150 & 250 & 180 & 180 & 175 & 335 & 195 & 185 \\
\hline \multirow[t]{2}{*}{$P$} & $\begin{array}{l}\text { mineral } \\
\text { organic }\end{array}$ & $\begin{array}{l}10 \\
35\end{array}$ & $\begin{array}{r}0 \\
30\end{array}$ & $\begin{array}{l}10 \\
30\end{array}$ & $\begin{array}{l}15 \\
20\end{array}$ & $\begin{array}{r}0 \\
35\end{array}$ & $\begin{array}{r}0 \\
30\end{array}$ & $\begin{array}{r}5 \\
60\end{array}$ & $\begin{array}{r}0 \\
35\end{array}$ & $\begin{array}{r}0 \\
30\end{array}$ \\
\hline & total & 45 & 30 & 40 & 35 & 35 & 30 & 65 & 35 & 30 \\
\hline \multirow[t]{2}{*}{ K } & $\begin{array}{l}\text { mineral } \\
\text { organic }\end{array}$ & $\begin{array}{r}115 \\
65\end{array}$ & $\begin{array}{l}45 \\
70\end{array}$ & $\begin{array}{l}95 \\
55\end{array}$ & $\begin{array}{l}75 \\
40\end{array}$ & $\begin{array}{l}20 \\
90\end{array}$ & $\begin{array}{l}30 \\
95\end{array}$ & $\begin{array}{r}0 \\
220\end{array}$ & $\begin{array}{r}0 \\
120\end{array}$ & $\begin{array}{r}0 \\
105\end{array}$ \\
\hline & total & 180 & 115 & 150 & 115 & 110 & 125 & 220 & 120 & 105 \\
\hline
\end{tabular}

Table 4. Annual costs (NLG $1000 \mathrm{ha}^{-1}$ ) of fertilization and crop protection, and average farm gross margin per system at the three experimental farms (legends: see Table 2).

\begin{tabular}{|c|c|c|c|c|c|c|c|c|c|}
\hline & \multicolumn{2}{|c|}{ Nagele ' $86-' 90$} & \multicolumn{3}{|c|}{ Borgerswold '86-' 90} & \multicolumn{4}{|c|}{ Vredepeel '89-'90 } \\
\hline & $C_{R}$ & I & $C_{R}$ & $\mathrm{C}_{\mathrm{LR}}$ & $I_{L R}$ & $I_{M R}$ & $\mathrm{C}_{\mathrm{R}}$ & $I_{R}$ & $\mathbf{I}_{\mathrm{L}}{ }^{\mathrm{R}}$ \\
\hline crop protection & 0.73 & 0.24 & 0.80 & 0.54 & 0.24 & 0.30 & 0.55 & 0.21 & 0.22 \\
\hline fertilization & 0.39 & 0.30 & 0.43 & 0.32 & 0.24 & 0.12 & 0.14 & 0.11 & 0.11 \\
\hline gross margin & 5.67 & 5.65 & 2.70 & 1.93 & 2.28 & 5.89 & 4.91 & 4.82 & 3.81 \\
\hline
\end{tabular}

The IFS fertilization strategy, based on a decrease of total nutrient input and substitution of expensive mineral and inorganic nutrients by cheap organic nutrients, reduces costs by NLG $140 \mathrm{ha}^{-1}$, NLG $190 \mathrm{ha}^{-1}$ and NLG $30 \mathrm{ha}^{-1}$ for Nagele, Borgerswold and Vredepeel, respectively (Table 4).

\section{Economic feasibility}

The Nagele results show that the net farm profit of the integrated system equals that of the conventional system (Vereijken, 1989c). The average gross margin of the integrated system equals that of the conventional system (Table 4). For Borgerswold and Vredepeel, a total economic evaluation still has to be made, so only gross margins are presented. The results for Borgerswold show that crop diversification causes a serious reduction in average gross margin. By utilizing the chances offered by a diversified rotation by an integrated management, the average gross margin can be improved.

The current difference in gross margin between the integrated $\left(\mathrm{I}_{\mathrm{LR}}\right)$ and conventional reference system is caused by some problems at the start (not corrected in the 


\section{F.G. WIJNANDS AND P. VEREIJKEN}

data presented) and the differences in cropping plan. If in the integrated system instead of once, sugar-beet is grown twice every 8 years, the gross margin would only fall short by NLG $100 \mathrm{ha}^{-1}$. If the results of 1986-1990 for Borgerswold are recalculated based on current prices, the integrated prototype improves the gross margin by approximately NLG $100 \mathrm{ha}^{-1}$ compared to the conventional system. These examples illustrate the need of optimization by economic modelling studies before and after the experiments.

The preliminary results of Vredepeel show a small difference in average gross margin between the conventional and integrated reference systems. After the usual conversion problems in the first year, the second year already showed a better result for the integrated reference system. This system is expected to equal or even exceed the conventional reference system. The more root-crop dominated integrated system clearly exceeds the reference systems by some NLG $1000 \mathrm{ha}^{-1}$, and the less rootcrop dominated system falls some NLG $1000 \mathrm{ha}^{-1}$ short in average gross margin compared to the intermediate systems. These effects are mainly caused by the choice of carrots as a financial high yielding crop. However, it is questionable whether the current rotation can maintain these yields.

Figure 1 shows promising results of IFS for the control of potato cyst nematodes at Borgerswold. The conventional system has the highest infestation despite frequent soil fumigation, which demonstrates the failure of chemical control of potato cyst nematode in 1:2 rotations. The population levels are quite similar in the integrated

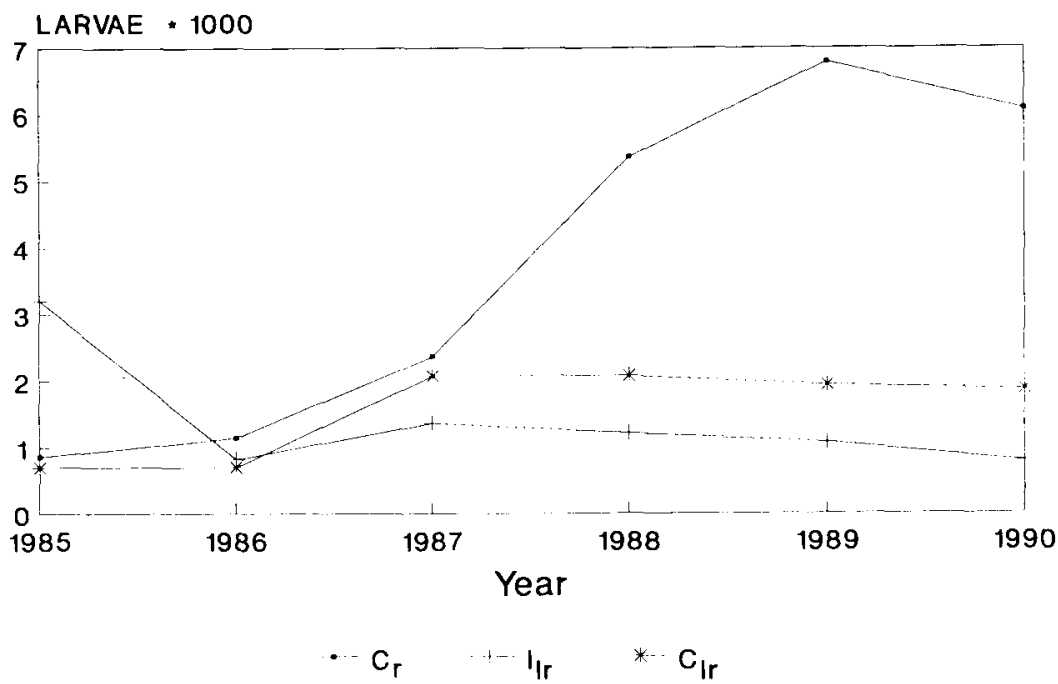

Fig. 1. Occurence of potato cyst nematodes in the three systems at Borgerswold 1986-1990 (average number of larvae $/ 100 \mathrm{cc}$ soil per field, samples $0-30 \mathrm{~cm}$ ) $\mathrm{C}_{\mathrm{R}}=1: 2$ potato; regular soil fumigation; alternating low and highly resistant cultivars; normal soil cultivation. $I_{L R}=1: 4$ potato; no nematicide use; highly resistant cultivars; minimal turning tillage. $C_{\mathrm{LR}}=1: 4$ potato; regular soil fumigation, alternating low and highly resistant cultivars, normal soil cultivation. 
and conventionally managed diversified systems. Obviously, soil fumigation can be substituted by the integrated control strategy for nematodes. Again, the question of sustainability of the IFS approach can only be answered on the longer term.

\section{Perspectives and constraints}

Following a regional problem analysis, specific IFS prototypes are being developed, based on suitable crop rotations and appropriate cropping systems. The preliminary results demonstrate that pesticide and nutrient inputs can be substituted for the greater part by non-chemical methods, with results after some optimization comparable to conventional systems. The strong reduction in pesticide inputs clearly exceeds the Netherlands' policy aims for 2000 (Table 5). Although nutrient inputs were reduced and inorganic fertilizers were for a great deal replaced by organic fertilizers, it might not be sufficient to meet the norm levels for $\mathrm{NO}_{3}$ in groundwater at the two sand locations, Borgerswold and Vredepeel. Therefore, additional research started in 1991. At Nagele (clay), leaching of $\mathrm{N}$ has been reduced by $20 \%$. The current level of leaching is not considered as problematic in relation to the quality demands for surface water or groundwater.

Considering the changing agricultural policy in the Netherlands and the promising IFS results, the conventional system at Nagele is no longer relevant. As a result, it will be replaced by an advanced integrated system. This change provides the experimental freedom to develop new methods and techniques aimed at further reductions in pesticide and nutrient input and output (emissions). The biodynamic mixed system is to be transformed into an arable/vegetable system, which corresponds better with the system of the organic farmers in the Netherlands. The current integrated system will aim at maintaining the low pesticide and nutrient input realized so far, and at optimization of the economic results.

At Borgerswold, crop extensification (less root crops) alone while maintaining conventional management leads to serious income losses. In this respect, standard economic calculations are correct. However, an IFS approach based on a less root-

Table 5. Percentual reductions in pesticide use $\left(\mathrm{kg}^{\mathrm{a}}\right.$ a. $\left.\mathrm{ha}^{-1}\right)$ of the IFS prototypes at the three experimental farms and the targeted reductions of the crop protection policy plan (Anonymous, 1991).

\begin{tabular}{|c|c|c|c|c|c|}
\hline & \multirow{2}{*}{$\begin{array}{l}\text { Nagele' }^{\prime} \\
{ }^{\prime} 86-' 90\end{array}$} & \multirow{2}{*}{$\begin{array}{l}\text { Borgerswold } \\
86 \text {-'90 }\end{array}$} & \multirow{2}{*}{$\begin{array}{l}\text { Vredepeel' }^{1} \\
\text { '89-'90 }\end{array}$} & \multicolumn{2}{|c|}{$\begin{array}{l}\text { Crop protection poli- } \\
\text { cy }\end{array}$} \\
\hline & & & & 1995 & 2000 \\
\hline herbicides & 65 & 64 & 67 & 30 & 45 \\
\hline fungicides & 62 & 49 & 50 & 15 & 25 \\
\hline insecticides & 60 & 99 & 50 & 15 & 25 \\
\hline total $^{2}$ & 63 & 54 & 55 & 20 & 33 \\
\hline nematicides & 100 & 100 & 100 & 50 & 70 \\
\hline
\end{tabular}

${ }^{1}$ Reduction in \% for the $I_{R}$ (Borgerswold $I_{L R}$ ) systems in comparison to the $C_{R}$ system.

2 Total concerns all pesticides excluding nematicides. 
crop dominated rotation may almost bridge the economic gap with the conventional reference system. Here, once again, the experimental design is adapted. The conventional system with less root crops is replaced by an IFS prototype aimed at maximum feasability and optimum economic results. The cropping frequency of the major cash crop, sugarbeet, is increased from $12.5 \%$ to $25 \%$ and the weed control strategy is adapted to minimum labour and machinery costs. The use of pesticides will then, of course, be reduced to a lesser extent than in the current integrated system. The development of the latter will be continued. The prevention of nitrate leaching will get priority in the years to come.

At Vredepeel, various crop rotations were laid out to reflect the range of farm conditions. The preliminary results show, however, that the pesticide and nutrient inputs are relatively independent of the crop rotation, with the exception of herbicides. Moreover, the economic profitability of the systems is more determined by the cropping plan than by integrated management of the crops. However, the major question will be the long-term effects of these rotations on soil-borne pests and pathogens. A major change in the objectives and set up of the less root-crop dominated system is being considered. Two changes are possible. First, an adaptation in crop choice, introducing more financially high-yielding vegetable crops, strictly alternating mono- and dicotylodonous crops to guarantee a quality production of the root crops and enhance the economic perspectives. This might be the most consistent integrated approach considering the problems. Second, alternation of grassland and arable crops taking into account the mixed structure of the area may be interesting. This regenerative approach would offer excellent opportunities to crop high quality vegetables and to minimize problems with soil-borne pest and pathogens, weeds and nutrient losses. Possibly a new layout will be implemented for the season 1993-1994.

The prospects for IFS in practice can only be evaluated in practice. Management is the key factor for the success and feasibility of an integrated approach. Therefore an experimental introduction on a number of pilot farms is considered to be an indispensable step before introducing IFS into practice (Vereijken, 1992; Wijnands, 1992).

\section{Development of IFS prototypes for outdoor horticulture}

\section{Introduction}

Outdoor horticulture in the Netherlands varies considerably in farm scale, crops and cropping systems. The holdings are small (2-10 ha) and concentrate around the most important auction centres. Since the land is cropped with a limited number of crops, the pressure of soil- and airborne pests and diseases is high. Consequently the pesticide input is high, however increasingly ineffective. In addition, high fertilizer inputs make crops more vulnerable to diseases and pests, cause too high contents of nitrate in certain produce, and pollute the environment. Prices are under pressure from overproduction and since costs are steadily increasing and the raising quality standards can often no longer be met anymore, the farm profits are decreasing. An integrated approach might solve the agronomic and environmental problems. But the economic problems probably remain, since allocated costs are just a fraction of the 
production value. Therefore, also the scale of activities should be enlarged by integrating horticulture with arable activities. This will also lead to the needed regional spreading of horticultural activities to prevent pests and diseases. Moreover, the high demands of exterior quality of the produce need to be reconsidered to permit farmers a less obligate use of pesticides. In the meantime, research has been started on the potential of IFS for outdoor horticulture.

\section{Layout of the IFS experiments}

Since 1990/1991, on four regional experimental farms, located in the heart of the main production areas, four systems are being studied differing in intensity of crop rotation. The most intensive system applies to small holdings specialized in a few crops (2-4 ha), and the most extensive system applies to larger holdings (20-30 ha) integrating vegetables and arable crops. This systematic approach should provide the needed data to evaluate the potential of IFS for a range of conditions in economic and agronomic model studies.

\section{Methods and techniques, constraints and perspectives}

The IFS strategies for arable farming can also be used for outdoor horticulture. However, integrated nutrient management (INM) cannot be introduced easily, since inputs are crop-based and largely exceed the farm output of nutrients so far. So a fertilization strategy at the farm level is lacking. The uptake of nutrients by vegetable crops is often substantially higher than what is harvested. Consequently crop residues are a major source of $\mathrm{P}$ and $\mathrm{K}$. This calls for an adapted INM strategy in vegetabledominated rotations. Considering the low farm output and the high soil reserves of nutrients, the input will generally be limited and directed to the most demanding crops, preferably in band applications. For nitrogen, it is aimed at moderate levels of available nitrogen by guided fertilization systems (Slangen et al., 1989), which also make it possible to account for nitrogen turnover from crop residues and green manure. New techniques to be used are band applications of fertilizers and 'fertigation' (combined fertilization and irrigation). Adaptations in the cropping plan should prevent nitrogen losses in wintertime.

Integrated crop protection in vegetables is still hampered by a lack of knowledge, particularly epidemiology in interaction with cropping measures and susceptibility of cultivars to local diseases. The crop protection strategy should include soil coverage techniques to prevent the occurrence of weeds and diseases and also nets to prevent insect attack. Integration of these techniques in practicable systems is one of the major topics for the next years. Since external quality is an essential requirement, pesticides should be substituted in a safe and efficient way. 


\section{F.G. WIJNANDS AND P. VEREIJKEN}

\section{References}

Aarts, H.F.M., E.E. Biewinga \& H. van Keulen, 1992. Dairy farming systems based on efficient nutrient management. Netherlands Journal of Agricultural Science 40: 285-299.

Anonymous, 1990. Agricultural Structure Memorandum: Government decision. (In Dutch). Ministry of Agriculture, Nature Management and Fisheries. SDU, The Hague. (Essentials available in English).

Anonymous, 1991. Multi-year Crop Protection Plan. Government decision. (In Dutch). Ministry of Agriculture, Nature Management and Fisheries. SDU, The Hague. (Essentials available in English).

Hofmeester, Y. \& F.G. Wijnands, 1990. Integrierter Ackerbau in den Niederlanden, Versuchsorganisation und Forschungsresultate. Mitteilungen der Österreichischen Bodenkundlichen Gesellschaft H. 42: 145-160.

Fry, W.E., 1978. Quantification of general resistance of potato cultivars and fungicide effects for integrated control of potato late blight. Phytopathology 68: 1650-1655.

Schomaker, C.H. \& T.H. Been, 1990. Reducing chemical control by early detection of small infestation foci of the potato cyst nematode. Annual Report 1989, p. 9-16. Research Institute for Plant Protection, Wageningen.

Slangen, J.H.G., H.H.H. Titulaer \& C.A.E. Rijkers, 1989. Nitrogen fertilizer recommendation with the KNS-system for iceberg lettuce (Lactuca sativa L. var. capitata) in field cropping. VDLUFASchriftenreihe 28, Kongressband 1988, Teil II: 251-261.

Vereijken, P., 1989a. From integrated control to integrated farming, an experimental approach. Agriculture, Ecosystems and Environment 26: 37-43.

Vereijken, P., 1989b. Experimental systems of integrated and organic wheat production. Agricultural Systems 30: 187-197.

Vereijken, P., 1989c. Research on integrated arable farming and organic mixed farming in the Netherlands. In: P. Vereijken \& D.J. Royle (Eds), Current status of integrated arable farming systems research in Western Europe, p. 41-50. IOBC/WPRS Bulletin 1989/XII/5.

Vereijken, P., 1990. Integrated nutrient management for arable farming. La Recherche Agronomique en Suisse 29: 359-365. (Also in German: 367-371).

Vereijken, P., 1992. A methodic way to more sustainable farming systems. Netherlands Journal of Agricultural Science 40: 209-223.

Vereijken, P. \& C.D. van Loon, 1991. A strategy for integrated low-input potato production. Potato Research 34: 57-66.

Vereijken, P. \& D.J. Royle (Eds), 1989. Current status of integrated arable farming systems research in Western Europe. IOBC/WPRS Bulletin 1989/XII/5, 76 pp.

Vereijken, P. \& F.G. Wijnands, 1990. Integrated agriculture into practice; strategy for farm and environment. (In Dutch). Publication No. 50. Research Station for Arable Farming and Field Production of Vegetables, Lelystad, $85 \mathrm{pp}$.

Wijnands, F.G., 1990. Farming systems research for integrated arable and organic mixed systems in the Netherlands. In: R. Unwin (Ed.), Crop protection in organic and low-input agriculture, p. 139-147. BCPC-Monograph no. 45, Cambridge.

Wijnands, F.G. \& P. Vereijken, 1989. Environmental and economic aspects of integrated sugar beet cropping on an experimental farm. Proceedings of the 52nd Winter Congress IIRB: 119-129.

Wijnands, F.G., 1992. Introduction and evaluation of integrated arable farming in practice. Netherlands Journal of Agricultural Science 40: 239-249.

Zadoks, J.C. (Ed.), 1989. Development of Farming Systems, evaluation of the five year period 1980-1984. Pudoc, Wageningen, 90 pp. 